\title{
Enrichment of Omega-3 from Anchovy (Stolephorus sp.) Fish Oil by Enzymatic Hydrolysis
}

\author{
Wawan Kosasih ${ }^{1,3^{*}}$, Raden Tina Rosmalina ${ }^{1}$, Mohamad Robi Muhdani ${ }^{2}$, Dede Zainal Arief $^{2}$, Endang \\ Saepudin $^{3}$, and Sri Priatni ${ }^{1}$
}

1) Research Unit for Clean Technology, Indonesian Institute of Sciences, Jl Sangkuriang Bandung 40135, Indonesia

2) Pasundan University, Jl Setiabudhi 193, Bandung 40153, Indonesia

3) Department of Chemistry, Faculty of Mathematics and Natural Sciences University of Indonesia, Building G, UI Depok Campus, Depok 16424, Indonesia

*Corresponding author : wawan.kosasih7@gmail.com

\begin{tabular}{|c|c|}
\hline$A R T I C L E \quad I N F O$ & Abstract \\
\hline $\begin{array}{l}\text { Revised date : } 2 \text { January } 2020 \\
\text { Accepted date: } 25 \text { February } 2020\end{array}$ & $\begin{array}{l}\text { Anchovy (Stolephorus sp.) is an economically important fish in Indonesia. } \\
\text { Anchovy contains Omega- } 3 \text { that is important to maintain the health of the heart } \\
\text { and brain. This study aimed to enrich the omega- } 3 \text { content of anchovy oil from } \\
\text { the North Sea of West Java. The extraction of anchovy oil was carried out by the } \\
\text { soxhlet method. Enrichment of omega- } 3 \text { from anchovy fish oil is carried out by } \\
\text { hydrolysis with a commercial lipase enzyme at a concentration of } 500,1000 \text {, } \\
1500 \text {, and } 2000 \text { unit } / 0.6 \mathrm{~g} \text { fish oil for } 5,10,15 \text { and } 20 \text { hours. Before enzymatic } \\
\text { hydrolysis by lipase, fish oil was added with water and organic solvent (ethanol, } \\
\text { toluene, n-hexane). The Omega- } 3 \text { content of fish oil products were analyzed by } \\
\text { using Gas Chromatography (GC) with FID detector with retention time } 14.068 \\
\text { min and } 15.506 \text { min for } \alpha \text {-Linolenat (ALA) and eicosapentaenoic (EPA), } \\
\text { respectively. The results showed that the highest omega- } 3 \text { content of ALA and } \\
\text { EPA were } 0.54 \text { and } 1.103 \% \text {, respectively that produced by the addition of n- } \\
\text { hexane was } 0.5 \mathrm{~mL} \text { and lipase activity of } 1000 \text { units for } 15 \text { hours of hydrolysis. }\end{array}$ \\
\hline \multicolumn{2}{|l|}{$\begin{array}{l}\text { Available online at: } \\
\text { https://doi.org/10.14203/jkti.v21i2.429 }\end{array}$} \\
\hline \multicolumn{2}{|l|}{ Keywords: } \\
\hline $\begin{array}{l}\text { Anchovy oil, Enzymatic reaction, } \\
\text { Lipase enzyme, Omega-3 }\end{array}$ & $\begin{array}{l}\text { (C) } 2020 \text { Indonesian Journal of Applied Chemistry. This is an open access article under the } \\
\text { CC BY-NC-SA license (https://creativecommons.org/licenses/by-nc-sa/4.0/). }\end{array}$ \\
\hline
\end{tabular}

\section{INTRODUCTION}

Indonesia was awarded a vast ocean with various of fish resources. Indonesia is the largest archipelago country in the world because it has a large sea area and a large number of islands. The length of Indonesia's coast reaches $95.181 \mathrm{Km}$ with sea area of 3.25 million $\mathrm{Km}^{2}$, mainland 2.01

66 | "Enrichment of Omega-3 from Anchovy (Stolephorus sp.) Fish Oil ...”: Wawan Kosasih, et.al. 
million $\mathrm{Km}^{2}$ and 2.55 million $\mathrm{Km}^{2}$ exclusive economic zone total territorial area of 7,81 million $\mathrm{Km}^{2}[1]$.

Indonesia as a country endowed with large marine resources, including the greatest richness of marine biodiversity. Anchovy is widely available in Indramayu's market. In this research, enrichment of omega- 3 content is carried out by enzymatic reaction using commercial lipase and anchovy oil obtained from fishermen of Indramayu beach.

Omega fatty acids (omega-3 and omega-6) are types of long-chain unsaturated fatty acids, Poly Unsaturated Fatty Acids (PUFA), which are essential or cannot be produced by a human body. Therefore, the intake of omega- 3 and omega- 6 nutrients derived from the food is needed. Adequate omega-3 and omega-6 intakes can optimize the growth of brain cells related to children's intelligence. The lack of omega-3 in the human body can cause fatigue, weak memory, depression, Alzheimer's, and schizophrenia [2,3]. In addition to omega-3, the intake of omega- 6 is also important, although the amount needed is less than the amount of omega-3 [4]. The lack of omega- 6 fatty acids can cause a decrease in growth rates, hair fall, infertility, fat infiltration in the liver, and scaly skin [5].

The most important omega-3 PUFAs are eicosapentaenoic acid (EPA; C20:5n-3) and docosahexaenoic acid (DHA; C22:6n-3) [6,7] and $\alpha$-linolenic acid (ALA; C18:3n-3) is important for the precursor of EPA and DHA [8]. On the other hand, high intakes of long-chain omega- 6 polyunsaturated fatty acids (Omega-6 PUFAs) have opposite properties than those of omega-3 PUFAs [9,10]. However, excessive consumption of omega- 6 without the consumption of omega-3 can reduce LDL (LowDensity Lipoprotein) cholesterol and also decreases HDL (High-Density Lipoprotein) cholesterol. If the level of LDL and HDL is not balanced, it will cause blood clots that trigger coronary heart disease [11].

Oleic acid (OA) is the major monounsaturated fatty acid (MUFA) present in salmon oil and belongs to the family of omega- 9 fatty acids, which correlates with the high MUFA content of fish oil with cardioprotective effects [12].

On the contrary, Palmitic acid (PA; C16:0) and OA affect cholesterol and fatty acid metabolism oppositely than oleic acid [13]. Saturated fatty acids (SFAs) affect involved factors in cholesterol metabolism[14]. For the aforementioned reasons, an in-depth knowledge of the presence and concentration of lipids in fish oil is mandatory.

Omega-3 fatty acids DHA (docosahexaenoic acid, C22:6 n-3), EPA (eicosapentaenoic acid C20:5 n-3) and Linolenic acid (C18:3 n-3) derived from fish oil are widely marketed across the world as valued dietary supplements offering numerous health benefits for children and adults alike [15].

DHA and EPA are important to prevent some diseases, including coronary heart disease, inflammation, hypotriglyceridemic effect, and diabetes [16,17].

Omega-3 PUFAs can be obtained from fish oils and marine microalgae and they have been purified using several procedures: urea complexation, chromatography, distillation, low-temperature crystallization, supercritical fluid extraction and enzymatic methods $[18,19]$. The main advantage of the enzymatic method is that low temperatures and non-aggressive reagents are used, which allows to maintain the PUFA structure unchanged. However, stable lipases, which are not deactivated in the reaction conditions, are essential for these processes to be economically viable [20].

During the last decade, several studies have shown positive effects of fish oils on cognitive development and vision enhancement in newborns, as well as in young children [21]. The aim of this study was to enrich the Omega- 3 (EPA and ALA) content of anchovy oil by the enzymatic hydrolysis method. 
pp. $66-73$, April 2020

\section{EXPERIMENTAL}

\subsection{Materials}

Anchovy (Stoleophorus sp.) was obtained from Indramayu, lipase enzyme (200,000 units / g) obtained from Xi'an Lyphar Biotech Company, Boron trifluoride-Methanol (BF3, 14\%) (E.Merck), n-Hexan (E. Merck), Methanol (E. Merck), DHA and $\alpha$-Linolenat (Sigma Chemical Co. St. Louis, USA), phosphate buffer pH 5.7 and other reagent were analytical grade.

\subsection{Methods}

Drying anchovy and extraction of fish oil was done one time, while the measurement of enzymatic reaction results was duplicated using GC.

\subsubsection{Anchovy flour Preparation [22]}

Anchovy sample was dried at $50^{\circ} \mathrm{C}$, for 48 hours. The dried sample was then crushed with a chopper to become anchovy flour. Fish oil was extracted from anchovy flour by using the soxhlet method.

\subsubsection{Anchovy Oil Extraction}

The extraction of fish oil was carried out by the soxhlet method. 80 grams of fish flour was wrapped in filter paper, then the wrapped flour was placed in the Soxhlet, and $300 \mathrm{~mL}$ of $\mathrm{n}$ hexane was added. This process was carried out for 8 hours, and n-hexane was evaporated.

\subsubsection{Characterization of Anchovy Oil}

\subsubsection{Determination of Iodine Numbers [23]}

0.3 grams of fish oil was added with $10 \mathrm{ml}$ of carbon tetrachloride and $20 \mathrm{ml}$ of iodinebromide. The solution was placed in a dark room for 30 minutes and shaked for each 10 minutes. $10 \mathrm{~mL}$ of $15 \% \mathrm{KI}$ and $100 \mathrm{~mL}$ of distilled water free of $\mathrm{CO}_{2}$ were added to the solution and then titrated with $0.1 \mathrm{~N} \mathrm{Na}_{2} \mathrm{~S}_{2} \mathrm{O}_{3}$ until the solution was pale yellow. Furthermore, into these solution was added $1 \mathrm{~mL}$ of starch solution and titrated until the blue color disappears. Iodine numbers can be calculated using the following equation:

$$
\begin{aligned}
& \text { Iodine number } \\
& =\frac{(b-a) X S . \text { Thiosulphate } X 126.9 \times 100}{g X 1000}
\end{aligned}
$$

Where:

$\mathrm{b}=$ Number of $\mathrm{mL} \mathrm{Na} \mathrm{S}_{2} \mathrm{O}_{3}$ blank titration

$\mathrm{a}=$ Amount of $\mathrm{mL} \mathrm{Na} \mathrm{S}_{2} \mathrm{O}_{3}$ titration of test substance

$\mathrm{g}=$ Sample Weight

$1 \mathrm{~mL}$ of $\mathrm{Na}_{2} \mathrm{~S}_{2} \mathrm{O}_{3}=0.01269 \mathrm{~g}$ Iodine

\subsubsection{Numbers of Free Fatty Acid (FFA) [24]}

Ten grams of oil was added $50 \mathrm{ml}$ of $95 \%$ ethanol and boiled for 10 minutes. The solution was added with 2 drops of $2 \%$ phenolphthalein and titrated with $0.1 \mathrm{~N} \mathrm{KOH}$ to form a pink color. The number of free fatty acids was calculated by equation.

$$
\% F F A=\frac{V K O H \times N K O H \times M W \text { fatty acid }}{\text { Sample Weight } x 10}
$$

Where :

$\mathrm{V}=\mathrm{KOH}$ volume of the titration result

$\mathrm{N}=$ Normality $\mathrm{KOH}$ used

MW = Molecular weight of dominant fatty Acids

\subsubsection{Enzymatic hydrolysis of fish oil}

0.6 gram of fish oil was added with $0.5 \mathrm{~mL}$ of an organic solvent (toluene, n-hexane, ethanol, water), lipase $0.5 \mathrm{~mL}$ (1000 unit, as written on the packaging 20.000 unit/g) in phosphate buffer and $0.1 \mathrm{M}$ of phosphate buffer $\mathrm{pH} 5.7$ until 3 $\mathrm{ml}$ of total volume. The solution was then incubated at room temperature and shaked at 150 rpm and 20 hours. The reaction was stopped by adding $2 \mathrm{~mL}$ of methanol. The same way was done for effect of $n$-hexane volume variations $(0.5,0.75,1$ and $1.25 \mathrm{~mL})$, effect of incubation 
time $(0,5,10,15$ and 20 hours) and enzyme concentration (0,1000, 1500 and 2000 unit).

\subsubsection{GC and GC-MS Sample Preparation (Sample Esterification)}

Firstly $0.125 \mathrm{~g}$ of fish oil was put in a test tube. Then, $0.5 \mathrm{ml}$ of boron trifluoride $\left(\mathrm{BF}_{3}\right)$ in $\mathrm{MeOH}(14 \%)$ was added to the test tube. Next, the test tube containing the fish oil and boron trifluoride $\left(\mathrm{BF}_{3}\right)$ in $\mathrm{MeOH}(14 \%)$ was incubated in an incubator shaker at $55^{\circ} \mathrm{C}$ for 1.5 hour. Then, $0.5 \mathrm{ml}$ of saturated sodium hydrogen carbonate $\left(\mathrm{NaCHO}_{3}\right)$ and $1.0 \mathrm{~mL}$ of $\mathrm{n}$-hexane was then added to the test tube. The mixture was mixed and shaken well using a vortex for about 30 second. Then, the mixture was stored at freezer for 10 minutes, so that it will form two layers. Lastly, $0.5 \mathrm{ml}$ of upper layer contain hexane was carefully transferred into a vial for GC and GCMS analysis.

\subsubsection{Gas Chromatography (GC) analysis}

Fatty acids composition of fish oil samples were analyzed using gas chromatography (GC) Agilent Technologies 7890B equipped with split injector, detector flame ionization detection (FID) system to separate and quantify each FAMEs components. FAMEs were separated using HP-5 column (30 m x $0.32 \mathrm{~mm}$ i.d, 0.25 ). Oven temperature was held at $100^{\circ} \mathrm{C}, 2 \mathrm{~min}$, then increased to $240^{\circ} \mathrm{C}$ at $10^{\circ} \mathrm{C} / \mathrm{min}$, held for $1 \mathrm{~min}$. Temperatures for injector and detector were set at $250^{\circ} \mathrm{C}$ and $300^{\circ} \mathrm{C} .1 \mu \mathrm{l}$ of sample was injected with ratio 100:1 at column temperature $100^{\circ} \mathrm{C}$. Carrier gases that were used for the system are helium gas $3.0 \mathrm{~mL} / \mathrm{min}$ controlled at $15.726 \mathrm{psi}$, hydrogen and air used for FID was held at 30 and $400 \mathrm{~mL} / \mathrm{min}$.

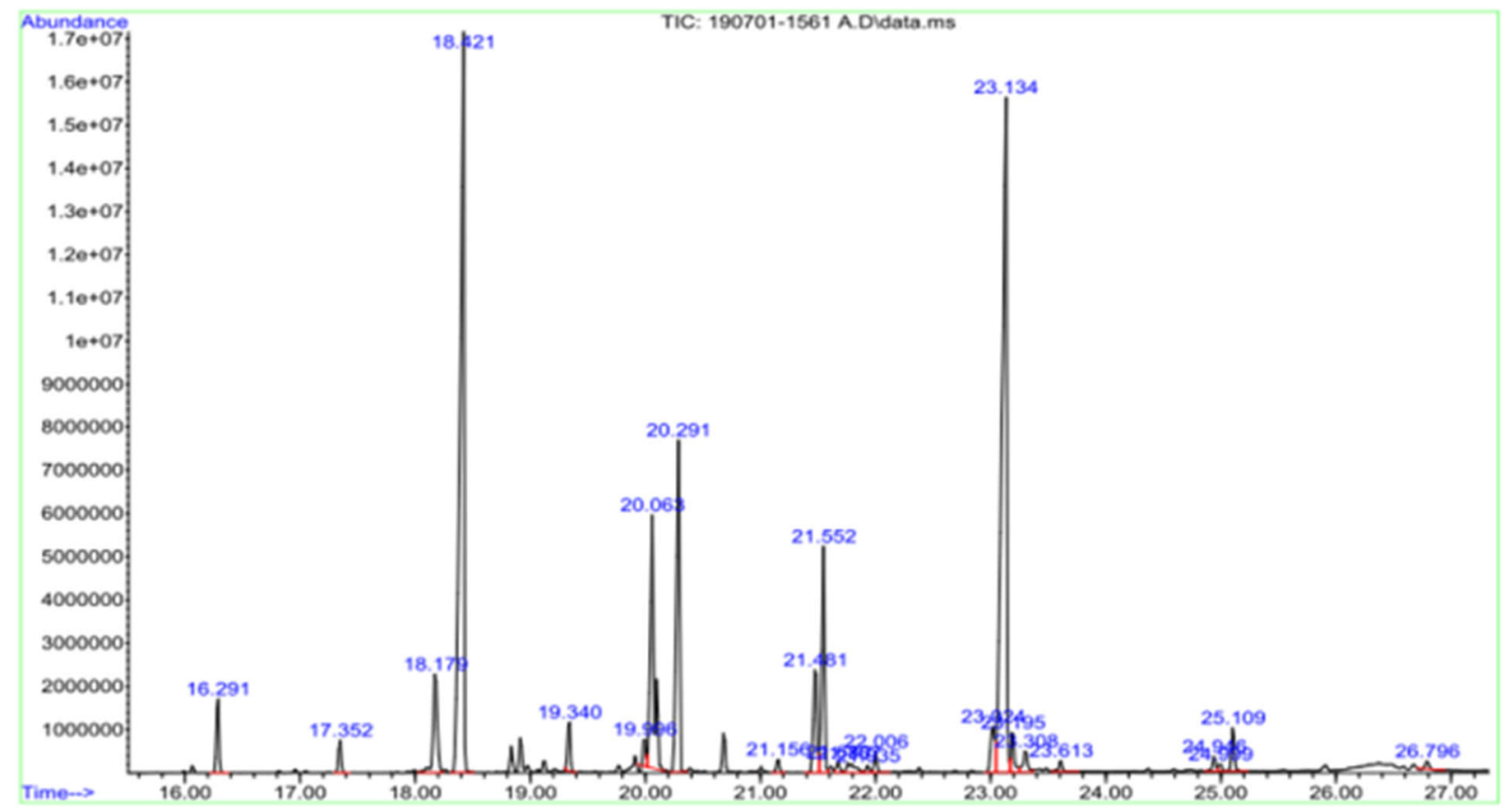

Fig. 1. Analysis of Anchovy Oil Used GCMS

\section{RESULT AND DISCUSSION}

Enrichment of omega-3 content in Anchovy oil has been carried out by enzymatic hydrolysis method using commercial lipase. Anchovy oil has been extracted from anchovy flour with the yield 5.09\%. The iodine number of Anchovy oil was $95.35 \mathrm{~g} \mathrm{I}_{2} / 100 \mathrm{~g}$ According to SNI proper oil consumed $>45-46 \mathrm{mg} / \mathrm{g}$. The higher the iodine number of oil, the more double bonds it has, the better its quality for consumption [24]. The fatty acid content of anchovies oil has been analyzed using GC-MS and the chromatogram was presented in Figure 1. 
pp. $66-73$, April 2020

Table 1. Fatty Acid profile in Anchovy Oil

\begin{tabular}{|c|c|c|}
\hline $\begin{array}{c}\text { RT } \\
\text { (Retention } \\
\text { Time) }\end{array}$ & Library/ID & $\begin{array}{c}\% \\
\text { Normal }\end{array}$ \\
\hline 16.291 & Methyl tetradecanoate & 1.916 \\
\hline 17.350 & $\begin{array}{l}\text { Pentadecanoic acid, methyl } \\
\text { ester }\end{array}$ & 0.795 \\
\hline 18.181 & $\begin{array}{l}\text { 9-Hexadecenoic acid, methyl } \\
\text { ester, (Z)- }\end{array}$ & 3.815 \\
\hline 18.421 & $\begin{array}{l}\text { Hexadecanoic acid, methyl } \\
\text { ester }\end{array}$ & 25.954 \\
\hline 19.341 & $\begin{array}{l}\text { Heptadecanoic acid, methyl } \\
\text { ester }\end{array}$ & 1.262 \\
\hline 19.996 & $\begin{array}{l}\text { 9,12-Octadecadienoic acid (Z, } \\
\text { Z)-, methyl ester }\end{array}$ & 0.635 \\
\hline 20.059 & $\begin{array}{l}\text { 11-Octadecenoic acid, methyl } \\
\text { ester }\end{array}$ & 9.435 \\
\hline 20.286 & Methyl stearate & 9.883 \\
\hline 21.156 & $\begin{array}{l}\text { Nonadecanoic acid, methyl } \\
\text { ester }\end{array}$ & 0.358 \\
\hline 21.483 & $\begin{array}{l}\text { 5,8,11,14-Eicosatetraenoic } \\
\text { acid, methyl ester, (all-Z)- } \\
5,8,11,14,17-\end{array}$ & 3.404 \\
\hline 21.546 & $\begin{array}{l}\text { Eicosapentaenoic acid, methyl } \\
\text { ester, (all-Z)- }\end{array}$ & 5.946 \\
\hline 21.685 & $\begin{array}{l}\text {.omega.-3 Arachidonic Acid } \\
\text { methyl ester }\end{array}$ & 0.328 \\
\hline 21.761 & $\begin{array}{l}\text { cis-11,14-Eicosadienoic acid, } \\
\text { methyl ester }\end{array}$ & 0.703 \\
\hline 21.937 & $\begin{array}{l}\text { 11-(3,4-Dimethyl-5-propyl-2- } \\
\text { furyl)-undecanoic acid, methyl } \\
\text { ester }\end{array}$ & 0.215 \\
\hline 22.000 & Eicosanoic acid, methyl ester & 0.520 \\
\hline 23.021 & $\begin{array}{l}\text { Methyl 4,7,10,13,16- } \\
\text { docosapentaenoate } \\
4,7,10,13,16,19-\end{array}$ & 1.665 \\
\hline 23.134 & $\begin{array}{l}\text { Docosahexaenoic acid, methyl } \\
\text { ester, (all-Z)- }\end{array}$ & 28.513 \\
\hline 23.197 & $\begin{array}{l}\text { Docosapentaenoic } \\
\text { methyl ester }\end{array}$ & 1.262 \\
\hline 23.311 & $\begin{array}{l}\text { 11-(3,4-Dimethyl-5-pentyl-2- } \\
\text { furyl)-dodecanoic acid, methyl } \\
\text { ester }\end{array}$ & 0.884 \\
\hline 23.613 & Docosanoic acid, methyl ester & 0.397 \\
\hline 24.949 & $\begin{array}{l}\text { 15-Tetracosenoic acid, methyl } \\
\text { ester, }(Z) \text { - }\end{array}$ & 0.450 \\
\hline 24.100 & $\begin{array}{l}15 \text {-Tetracosenoic acid, methyl } \\
\text { ester, }(Z) \text { - }\end{array}$ & 0.217 \\
\hline 25.113 & $\begin{array}{l}\text { Tetracosanoic acid, methyl } \\
\text { ester }\end{array}$ & 1.261 \\
\hline 26.802 & $\begin{array}{l}\text { Hexacosanoic acid, methyl } \\
\text { ester }\end{array}$ & 0.183 \\
\hline
\end{tabular}

Based on the data from GSMS chromatogram, The types of fatty acids profile derived from anchovy oil was presented in Table 1 .
Based on the data from GCMS database, Anchovy oli contain 24 fatty acids in esters form with the highest content of unsaturated fatty acid was successively 4,7,10,13,16,19Docosahexaenoic acid or DHA (28.513\%), 11Octadecenoic acid (9.43\%) and 5,8,11,14,17Eicosapentaenoic acid or EPA $(5.95 \%)$. On our previous study, fish oil from Boso fish using soxhlet extraction and hydrolyzed by lipase produced $10.76 \%$ of omega- 6 and $13.84 \%$ of omega-9, higher than without lipase $(6.31 \%$ of omega-6 and $12.81 \%$ of omega-9) [22]. Anchovy has better potential than Boso fish for omega-3 production. Boso fish oil before the enzymatic reaction or after the enzymatic reaction does not appear to contain omega-3s.

In this study, the effect of the organic solvent in enzymatic process was evaluated by using some solvent such as water, toluene, ethanol and hexane. The fatty acids content linolenic acid (ALA) and eicosapentaenoic acid (EPA) of the hydrolysis products was then analyzed by using GC-FID. The effect of the organic solvent in enzymatic process on ALA and EPA content was presented in Table 2.

Table 2. The effect of organic solvent on enrichment of Omega-3 (ALA and EPA) content in lemuru fish oil

\begin{tabular}{ccc}
\hline \multirow{2}{*}{ Type of Solvent } & \multicolumn{2}{c}{ Content (\%) } \\
\cline { 2 - 3 } & EPA & ALA \\
\hline Control & 0.14 & 0.32 \\
Water & 0.12 & 0.32 \\
Toluena & 0,09 & 0.25 \\
Ethanol & 0.15 & 0.35 \\
n-Hexane & 0.16 & 0.44 \\
\hline
\end{tabular}

The data on Table 2 showed that the highest EPA (0.16\%) and ALA (0.44\%), was obtained when n-hexane is used in enzymatic reaction. Enzymatic hydrolysis with the addition of hexane, heptane and toluene solvents can increase the catalytic activity of enzymes [25]. The study was continued to find the optimum concentration of n-hexane in hydrolysis of

70 | "Enrichment of Omega-3 from Anchovy (Stolephorus sp.) Fish Oil ...”: Wawan Kosasih, et.al. 
pp. $66-73$, April 2020

Omega-3 in Anchovy fish oil and the results is presented in Figure 2.

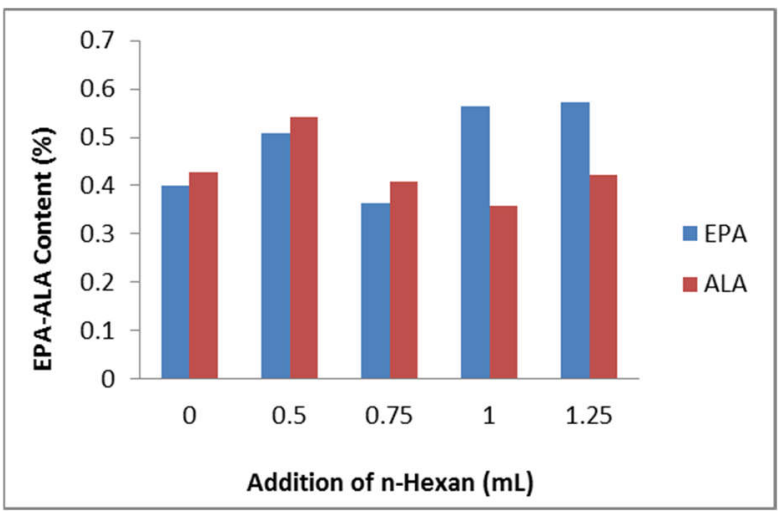

Fig. 2. The effect of $n$-hexane concentration on enrichment of Omega-3 (ALA and EPA) content in Anchovy fish oil

The data on Figure 2 showed that the optimum addition of $\mathrm{n}$-hexane was $1.25 \mathrm{~mL}$ for EPA and $0.5 \mathrm{~mL}$ for ALA (total volume of reaction $3 \mathrm{~mL}$ ). The addition of $n$-hexane volume affected the EPA and ALA content. The addition of organic solvent can increase the thermostability of lipase. Hydrophobic properties of organic solvent will depend on some parameters such as dielectric constant, dipole moment and $\log \mathrm{P}$ value. Hexane is known has a $\log \mathrm{P}$ value (3.5) higher than toluene (2.5). [26]

To optimize the enzymatic hydrolysis of anchovy oil by lipase, in this study was evaluated the effect of incubation time and enzyme concentration to Omega-3 content. The results was presented in Figure 3.

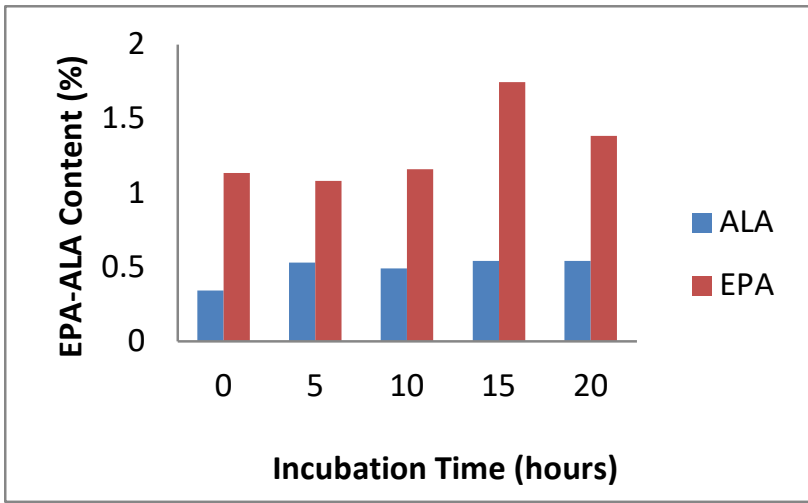

Fig. 3. The effect of incubation time on enrichment of Omega-3 (ALA and EPA) content in Anchovy fish oil
Reaction time is one of parameters for an enzyme to catalyze and generate the product. Long reaction time is not effective and likely to suffer from substrate reformation due to reversible property of an enzyme. This phenomenon can be observed in Figure 4 as Lipase is used to hydrolyze triglycerides:

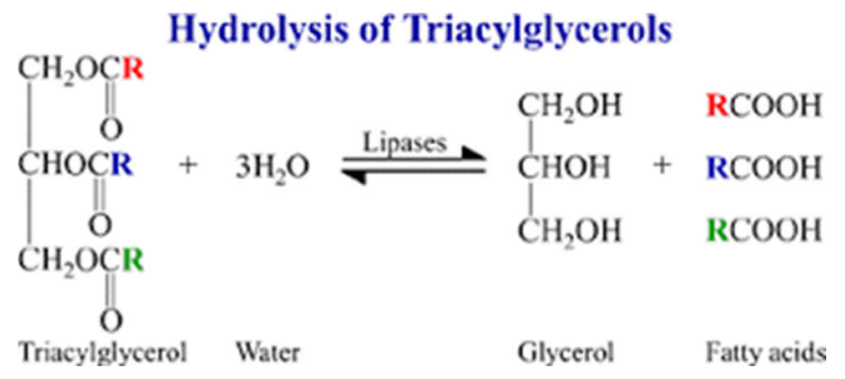

Fig. 4. The mechanism of the triacylglycerol hydrolysis reaction by the lipase enzyme [28].

The data on Figure 3 showed that the highest of EPA $(1.75 \%)$ and ALA $(0.54 \%)$ content was reached after 15 hours incubation time.

The study was continued to evaluate the optimum of enzyme concentration in enzymatic hydrolysis process.

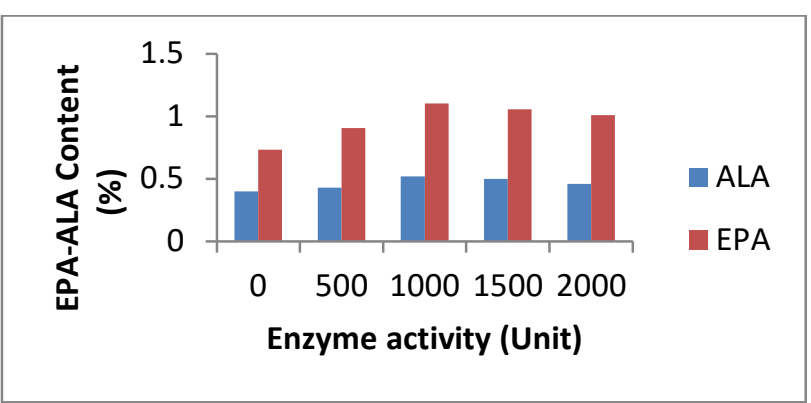

Fig. 5. The effect of enzyme activity on enrichment of Omega-3 (ALA and EPA) content in Anchovy fish oil

On Figure 5 showed that the optimum enzyme concentration was 1000 units per $0.6 \mathrm{~g}$ of fish oil with the concentration of EPA and ALA are respectively $1.103 \%$ and $0.520 \%$. Lipase was concentrated the polyunsaturated fatty acids such as EPA and DHA. The ester bond between glycerol and monounsaturated fatty acid and saturated fatty acid was cleaved by lipase [27]. Based on the data on Figure 5, the increasing of 
EPA and ALA concentration are between 30$50 \%$, after hydrolysis with lipase (1000 unit) for 15 hours. A probable explanation for the low lipase activity is the structure of enzyme, which do not accommodate the esters of PUFA from Anchovy oil in their active sites.

\section{CONCLUSION}

Enrichment of Omega-3 anchovy oil by hydrolysis using the commercial lipase enzyme was successfully carried out. The addition of 0.5 $\mathrm{mL} \mathrm{n}$-hexane solvent, lipase activity of 1000 units / 0.6 gram fish oil and 15 hours incubation time were the most optimum conditions to produce EPA and ALA with concentration of 1.103 and $0.520 \%$, respectively.

\section{ACKNOWLEDGMENT}

The authors gratefully thank to INSINAS program for funding for research. The authors also thank to Research Unit for Clean Technology for laboratory facilities.

\section{REFERENCES}

[1] Ministry of Maritime Affairs and Fisheries Republic of Indonesia http://www2.kkp.go.id/artikel/2233maritim-indonesia-kemewahan-yang-luarbiasa, Accessed on Pebruary 6, 2020

[2] De Busk R, Omega-3 Fatty Acids 2007, 225 http://www.umm.edu/omega-3 000316.htm

[3] Stoimeova A, Obreskova D, Petrov G, Peikova L, Hadjieva B, and Bojkova M, 2013 Pharmacia 22760 26-30

[4] Diana F M 2012 J. Kesehatan Masyarakat 6 113-7Bbvn

[5] Gibson R A Essential fatty acids and eicosanoids ed Sindair A J and Gibson R A (Illinois: 230 AOCS Books) 1993 p 210

[6] Calder, P. C., \& Yaqoob, P. Understanding omega-3 polyunsaturated fatty acids.
Postgraduate Medicine, (2009);121(6): 148-157. http://dx.doi.org/10.3810/pgm

[7] [8] Kaur, G., Cameron-Smith, D., Garg, M., \& Sinclair, A. J. Docosapentaenoic acid

[8] (22:5n-3): A review of its biological effects. Progress in Lipid Research. (2011);50(1):28-34.

http://dx.doi.org/10.1016/j.plipres.2010.0 7.004

[9] Covas, M. I., Ruiz-Gutierrez, V., de la Torre, R., Kafatos, A., Lamuela-Raventós, R. M.,Osada, J., ... Visioli, F.. Minor components of olive oil: Evidence to date of health.Nutrition Reviews (2006);64:S20-S30. http://dx.doi.org/10.1301/nr.2006.oct.S20

[10] Patterson, E., Wall, R., Fitzgerald, G. F., Ross, R. P., \& Stanton, C. Health implicationsof high dietary omega- 6 polyunsaturated fatty acids. Journal of Nutrition andMetabolism. (2012). http://dx.doi.org/10.1155/2012/539426

[11] Rose D P and Connolly J M.. Therapeut. Pharmacol 1999; 83: 217-44

[12] Wu, Y., Song, P., Xu, J., Zhang, M., \& Zou, M. Activation of protein phosphatase 2Aby palmitate inhibits amp-activated protein kinase. Journal of Biological Chemistry.(2007); 282: 9777-9788. http://dx.doi.org/10.1074/jbc.M60831020 $\underline{0}$

[13] Mensink, R. P. Health effects of saturated fatty acids. In Reference module in biomedical sciences encyclopedia of human nutrition. (2013); Vol. 2:pp. 215-219.

[14] Ciriminna R, Meneguzzo F, Delisi R, and Pagliaro M. Sustain. Chem. Pharm. (2017); 5: 54-9

[15] Malasanos T H and Stacpoole P W. Diabetes Care. ( 1991) ;14: 1160-79

[16] [16] Garcia D G. Food Technol. ( 1991); 52: 44-9

[17] Colombo J, Shaddy D J, Andreson C J, Blaga O M, Kannaus K N and Kundurthi S. 4 Child Development. (2007);5:125467

72 | "Enrichment of Omega-3 from Anchovy (Stolephorus sp.) Fish Oil ...”: Wawan Kosasih, et.al. 
pp. $66-73$, April 2020

[18] F. Shahidi, U.N. Wanasundara, Omega-3 fatty acid concentrates: nutritionalaspects and production technologies, Trends Food Sci. Technol. 9 (1998)230-240.

[19] N. Rubio-Rodríguez, S. Beltrán, I. Jaime, S.M. de Diego, M.T. Sanz, J.R. Carballido,Production of omega-3 polyunsaturated fatty acid concentrates: a review,Innov. Food Sci. Emerg. Technol. 11 (2010) 1-12.

[20] Lorena Martín Valverde, Pedro A. González Moreno, Luis Esteban Cerdán, Elvira Navarro López, Beatriz Castillo López, Alfonso Robles Medina, Concentration of docosahexaenoic and eicosapentaenoic acids by enzymatic alcoholysis with different acyl-acceptors. (C) 2014 Elsevier B.V. All rights reserved

[21] Stonehouse W, Does Consumption of LC Omega-3 PUFA Enhance Cognitive Performance in Healthy School-Aged Children and throughout Adulthood? Evidence from Clinical Trials, Nutrients. 2014 Jul 22;6(7):2730-58. doi: 10.3390/nu6072730. Review

[22] W Kosasih, S Priatni, E Saepudin, R T Rosmalina, S Nurasiah and E S Endah. Isolation and characterization of Boso fish (Oxyeleotris marmorata) oil and their recovery using enzymatic reaction. (2019)IOP Conf. Series: Earth and Environmental Science 277 (2019) 012006. doi:10.1088/1755$1315 / 277 / 1 / 012006$

[23] Departemen Kesehatan Republik Indonesia. 1979. Farmakope Indonesia Edisi III. Jakarta : Departemen Kesehatan Republik Indonesia

[24] AOAC. 1990. Official Methods of Analysis of the Association of Official Analytical Chemist 15th ed. Washington: AOAC Inc

[25] Raharja S, Suparno O, Mangunwidjaja Dj, Herdiyani A, Oktavia T, Najah Z. Penambahan pelarut organik pada media untuk hidrolisis enzimatik minyak ikan menggunakan lipase dari Aspergilus niger. Jurnal Teknologi Industri Pertanian (2012), 22 (3):140-150

"Enrichment of Omega-3 from Anchovy (Stolephorus sp.) Fish Oil ...”: Wawan Kosasih, et.al.|73
[26] Baharum SN, Salleh AB, Razak CNA, Rahman MBA, Rahman RNZRA. 2003. Organic Solvent Tolerant by Pseudomonas sp. Strain S5: Stability of Enzyme in Organic Solvent and Physical Factors Affecting Its Production. J Annals Microbiol. 53: 75-83

[27] Iberahim, N.I., Z. Hamzah, Y.J. Yin, and K.S.A. Sohaimi. 2018. "Extraction and Characterization of Omega-3 Fatty Acid from Catfish Using Enzymatic Hydrolysis Technique." MATEC Web of Conferences 187: 01005.

[28] Kulkarni, N, Studies on lipase enzyme from Pseudomonas Fluorescens NS2W, Chemical Engineering Division National Chemical Laboratory Pune 411008 (India) page 1-5, 2002 